\title{
As lutas pela Amazónia no início do milénio
}

Pedro Hespanha e Luis E. Aragón

\section{OpenEdition}

\section{Journals}

Edição electrónica

URL: http://journals.openedition.org/rccs/5980

DOI: $10.4000 /$ rccs.5980

ISSN: 2182-7435

\section{Editora}

Centro de Estudos Sociais da Universidade de Coimbra

Edição impressa

Data de publição: 1 setembro 2015

Paginação: 03-04

ISSN: 0254-1106

\section{Refêrencia eletrónica}

Pedro Hespanha e Luis E. Aragón, « As lutas pela Amazónia no início do milénio », Revista Crítica de

Ciências Sociais [Online], 107 | 2015, posto online no dia 04 setembro 2015, consultado o 25 setembro 2020. URL : http://journals.openedition.org/rccs/5980 ; DOI : https://doi.org/10.4000/rccs.5980 


\section{As lutas pela Amazónia no início do milénio}

O processo de globalização, a mundialização dos mercados, o extraordinário avanço das telecomunicações, a modernização dos transportes, o fortalecimento da sociedade e do mercado do conbecimento, entre outros fatores, modificaram profundamente a geografia mundial, trazendo à tona questionamentos diversos sobre o rumo que tomou a sociedade num mundo extremamente injusto e desigual que, ao que tudo indica, tende a agravar-se.

No atual contexto internacional assiste-se uma nova organização das atividades económicas e vive-se acirrada disputa entre as potências detentoras da moderna tecnologia, localizada nos países hegemónicos, e países detentores dos maiores estoques de natureza, localizados principalmente em países periféricos. E nesse contexto a Amazónia ganha um papel preponderante pelo enorme estoque de recursos naturais que possui e pelo seu papel crucial nas mudanças climáticas globais.

Mas essa disputa não opera num espaço vazio. Por isso, a disputa pelos recursos naturais é antes de mais uma disputa pelo controlo dos recursos das comunidades amazónicas e, através destes, pelas condições de existência autónoma dessas próprias comunidades. Neste sentido, o futuro da Amazónia só pode ser perspetivado no quadro mais geral das lutas pela Amazónia e estas decorrem tanto da imposição de um modelo de desenvolvimento associado aos processos de globalização hegemónica, quanto do reconbecimento de um modelo de desenvolvimento intercultural associado à preservação da diversidade social e cultural dos povos amazónicos.

Este número da Revista Crítica de Ciências Sociais ocupa-se da "questão amazónica", publicando um conjunto de textos que foram elaborados no âmbito de um colóquio realizado pelo Centro de Estudos Sociais em 2012, associado ao Programa Cátedra Milton Santos, precisamente com o título "As Lutas pela Amazónia no Início do Milénio".

Luis E. Aragón, primeiro titular da Cátedra Milton Santos, no seu artigo "Desenvolvimento amazônico em questão", faz uma sintese dos principais desafios de trabalhar com o conceito de desenvolvimento sustentável para entender a questão da Amazónia, apontando a necessidade de integrar um conjunto vasto de dimensões nesse conceito, tais como a da invenção da Amazónia, a das desigualdades regionais, a do lugar dos conhecimentos locais, a da globalização económica, a da biopirataria e a das novas lideranças, entre outras. 
Mario Miguel Amin, em "A Amazônia na geopolítica mundial dos recursos estratégicos do século XXI", apresenta a região como espaço vital para o futuro, dentro do paradigma da globalização que definiu, a partir dos anos 1980, uma nova configuração geopolítica determinada pela crescente procura internacional de recursos naturais estratégicos. Essa nova realidade geopolítica exige uma maior presença do Estado a fim de garantir o desenvolvimento sustentável da Amazónia e reafirmar a soberania dos países amazónicos sobre a região.

Alberto Acosta, no artigo "Amazonia. Violencias, resistencias, propuestas", argumenta que esse território tem vida própria e gera múltiplos saberes que o modelo de desenvolvimento ocidental tenta calar, convertendo-se por isso mesmo em lugar de lutas e resistências. Entende que é urgente, portanto, buscar saidas globais e locais integrais que possibilitem a transição para uma sociedade baseada nos princípios do "bom viver".

Carlos Walter Porto-Gonçalves, no seu artigo "Amazônia enquanto acumulação desigual de tempos: Uma contribuição para a ecologia política da região", analisa a complexa e contraditória dinâmica sociogeográfica, destacando as múltiplas territorialidades presentes na Amazónia, de onde surgem diversas possibilidades para o futuro da região.

Alex Fiuza de Mello, no seu artigo "Dilemas e desafios do desenvolvimento sustentável da Amazônia: O caso brasileiro", argumenta que o progresso material sem desenvolvimento sustentável tem sido a trajetória histórica das sociedades amazónicas. Nesse sentido, os modelos de desenvolvimento regional reproduzem, até hoje, as características de dependência local aos padrões de acumulação gerados externamente, condenando a Amazónia tão-somente a um simples "almoxarifado" do grande capital. Os desafios futuros implicam, portanto, uma rutura com esse modelo tradicional de dependência, questão que envolve, entre outros fatores, fortes investimentos na educação, ciência e inovação.

Pedro Hespanha e Luis E. Aragón

\section{Pedro Hespanha}

Centro de Estudos Sociais, Universidade de Coimbra

Colégio de S. Jerónimo, Largo de D. Dinis, Apartado 3087, 3000-995 Coimbra, Portugal

Contacto: hespanha@ces.uc.pt

\section{Luis E. Aragón}

Núcleo de Altos Estudos Amazônicos, Universidade Federal do Pará

Cidade Universitária Professor José da Silveira Netto, Rua Augusto Correa, 1, Guamá

66075-750 Belém, Pará, Brasil

Contacto: luis.ed.aragon@hotmail.com 